\title{
Health Promotion with Counseling on Fulfilling Balanced Nutritional Needs for Community Groups in Pandemic Covid-19 Outbreak
}

\author{
Nurhidayata), Suhanda, Doni Setiawan, Heri Ariyanto, and Henri Setiawan
}

STIKes Muhammadiyah Ciamis, Ciamis, Indonesia

a)Corresponding author: henrisetiawan1989@gmail.com

\begin{abstract}
Covid-19 pandemic could increase forms of malnutrition such as overweight and micronutrient deficiencies. Fruits and vegetables are the best sources of vitamins and minerals. The content of vitamins and minerals can act as antioxidant compounds. The method used in this service activity consists of the planning stage, the implementation of the activity, and ends with an evaluation as a measure of the level of success. Health education is carried out by means of lectures and question and answer sessions, educational media using leaflets and PowerPoint Presentations. Results: the evaluation shows that the activities have been carried out well in accordance with the results indicators and criteria on the Evaluation Sheet instrument. The sheet is based on five dimensions, namely Punctuality and Duration, Participation, Knowledge, Job Description and Problem Solving. The content of the evaluation is carried out by two independent observers.
\end{abstract}

Keywords : counseling, health promotion, nutrition

\section{INTRODUCTION}

A prolonged Covid-19 pandemic can increase forms of malnutrition such as being overweight and micronutrient deficiencies. Implementing health protocols such as washing hands, maintaining distance and wearing masks, are recommended ways to prevent contracting the Covid-19 virus (Akbar \& Aidha, 2020). Government policies that limit community mobilization greatly affect the food system by disrupting the production, transportation, and sale of nutritious, fresh, and affordable food. So that it can cause people to depend on alternative foods that are poor in nutrition. Therefore, this policy, indirectly affects the economic condition of the community, so that it has an impact on the community's ability to meet their daily food needs (Tuwu, 2020).

Eating unhealthy foods such as snacks that are high in sugar, high in energy, and high in saturated fat, can lead to health problems such as hypertension, being overweight, to hyperlipidemia (Fitri, Hendra, \& Rahmad, 2020). The existence of an imbalance between food intake and body needs accompanied by infectious diseases is a factor causing nutritional problems in the community. Understanding and practicing healthy lifestyles in the community through fulfilling balanced nutrition based on nutritional principles is an effort that can be done to prevent nutrition-related problems in the community (Ronitawati et al., 2020).

It is necessary to apply the principle of balanced nutrition, which is expected to improve the nutritional status of the community optimally, especially during the Covid-19 pandemic, everyone is advised to maintain a good and healthy diet. Although there are no certain types of food ingredients or supplements that can prevent the spread of the Covid-19 virus, starting to change dietary habits such as eating a balanced diet is known to increase immunity and reduce the risk of disease due to infections and chronic diseases (Astika, Permatasari, \& Turrahmi, 2021).

Nutrition has a big role for optimal health of an individual. Adequate and balanced nutrition is needed to be able to carry out activities optimally without experiencing fatigue. If nutrition is not met adequately and in a balanced manner, it will interfere with metabolic processes and result in nutritional problems (Firmansyah et al., 2021; Setiawan et al., 2021. Conversely, if nutrients are consumed in excess, it will cause health problems such as abnormal increases in body weight, 
blood glucose, blood pressure, and blood lipid profiles (triglycerides, cholesterol, VLDL, LDL, HDL). In adulthood, more nutrients are needed to prevent disease and promote health. Individuals often begin to feel aware of the meaning of their body's health when they are sick, not least for people entering young adulthood. Young adults are those who are 19-24 years old, that is when, a person is going through the transition from adolescence to old age (Hidayah, Izah, \& Andari, 2020)

People need balanced nutritional food to increase body resistance. The content of both micro and macro nutrients in food is known to increase people's immunity (Setiawan, Khairunnisa, \& Oktavia, 2021). To maintain an optimal immune system, it is very important to have a nutritious diet, especially those containing vitamins and minerals in the daily diet. Fruits and vegetables are the best sources of vitamins and minerals. The content of vitamins and minerals can act as antioxidant compounds that can increase the body's immunity so that it helps in preventing the Covid-19 virus. This can be done by promoting health (Promkes) to the community (Debora Tisa $\mathrm{Br} \mathrm{H} \&$ Wahyudi, 2020).

Health education is a health education activity carried out by spreading messages, instilling confidence, so that people are aware, know and understand, but are also willing and able to make recommendations related to health (Setiawan et al., 2018). Health education is essentially an activity or effort to convey health messages to the public, groups, or individuals so that they can gain knowledge about health which has an impact on behavior change (Mahmudah, 2020).

\section{METHOD}

The Community Service Activities carried out are a collaboration between the Research and Community Service Institute (LPPM) STIKes Muhammadiyah Ciamis and the LazisMu Ciamis Humanitarian Institution which consists of 3 stages, namely planning, implementation and evaluation. Planning activities begin with a situation analysis based on the D-III Nursing Study Program roadmap of STIKes Muhammadiyah Ciamis regarding research and community service. After the formation of the committee and activity personnel, a preliminary study was carried out to determine the right time, place and topic according to the needs of the local community.

Intensive coordination was carried out with the Ciamis Regency government which was delegated to the Regional Technical Implementation Unit (UPTD) of the Pamarican District Health Center, religious leaders, community leaders and leaders at the RT/RW level, Lurah and Village Heads. This aims to ensure that the series of activities can be socialized to all levels of society who are participants in Community Service activities.

The activity was carried out at the Pamarican Village Hall on March 31, 2021, from 08.30 10.00. The number of committee involved is eight people, which is a combination of LPPM STIKes Muhammadiyah Ciamis and the LazisMu Humanitarian Institution of Ciamis Regency. Moderators, Operators, Observers and Resource Persons are members of the community service team. Participants who took part in the counseling were 76 people from Pamarican Village.

Counseling is carried out by referring to the Extension Program Unit (SAP), which has been prepared, namely:

\section{Opening}

Saying greetings.

\section{Introduction}

The moderator introduces himself and reads the curriculum vitae of the resource person.

\section{Pre-Implementation Evaluation}

The evaluation in this section aims to explore participants' knowledge about the topics to be presented including the definition of nutrition and nutrition, various types of nutrition and nutrition, examples of foods that contain nutrients and nutrients, and the impact of nutritional and nutritional deficiencies. The method used is direct question and answer between the informants and 
participants at random. Initially, the resource person gave prepared questions and then gave an open opportunity to all participants to answer these questions. Next, the resource person appointed four other participants at random to answer the questions.

\section{Main Material}

Submission of the main material is done by the lecture method. The resource person first conveys the objectives and criteria for the results of the activities held. Furthermore, the speakers sequentially delivered the material using PowerPoint presentation media. The main material presented is the definition of nutrition and nutrition, various kinds of nutrition and nutrition, foods and drinks that contain nutrition and nutrition, the impact of nutritional and nutritional deficiencies, as well as compiling a balanced nutritional menu.

\section{Discussion}

After the main material is presented, the moderator opens the opportunity for all participants to ask questions about the material that still requires explanation. The discussion session was opened for two terms, and each term was given the opportunity for three participants.

\section{Post-Implementation Evaluation}

Post-Implementation Evaluation aims to explore participants' knowledge after the counseling is given. In the first term, the resource person randomly appointed three participants to answer the prepared questions. While in the second term, the resource person provided an open opportunity for all participants to answer questions.

\section{Clossing}

The moderator delivered the conclusion of the entire series of events and closed with a prayer and closing greetings.

The last stage is evaluation. All teams involved in outreach activities conduct evaluations based on the indicators and outcome criteria listed in the SAP. The checklist or evaluation sheet is prepared by the observer to control the series of extension activities so that the evaluation notes can be discussed in the evaluation activities. In general, the activity implementation protocol can be seen in the image below.

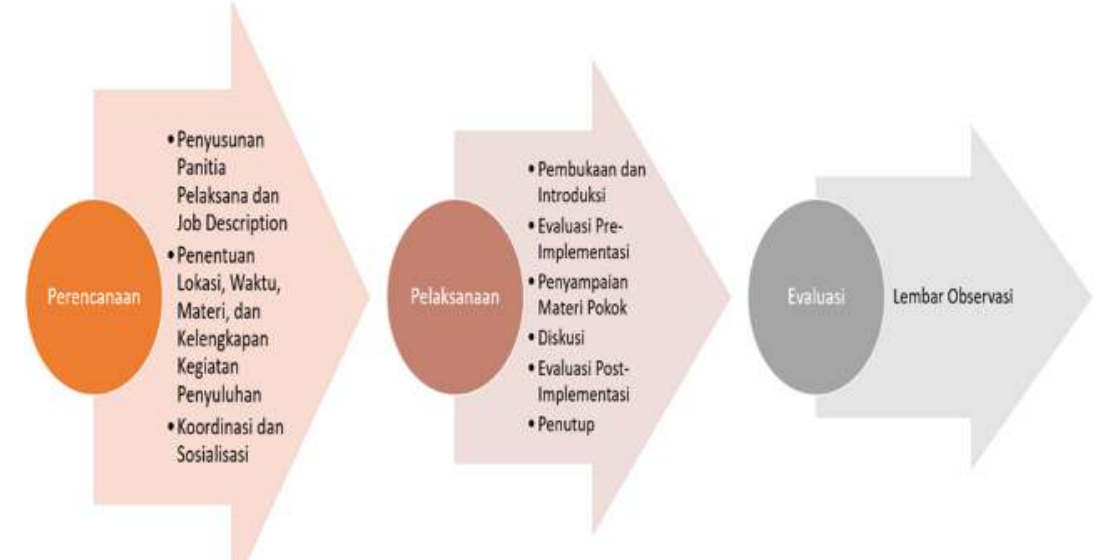

Figure 1. Conceptual Framework for Extension Activities

\section{RESULT AND DISCUSSION}

The results of the evaluation show that the activities have been carried out well in accordance with the results indicators and criteria on the Evaluation Sheet instrument. The Evaluation Sheet is based on five dimensions, namely Timeliness and Duration, Participation, Knowledge, Job Description and Problem Solving. The evaluation sheet was filled out by two independent observers (Setiawan, Ariyanto, Firdaus, \& Khaerunnisa, 2021). 


\section{Punctuality and Duration}

Timeliness and duration are one of the important dimensions in measuring the success of an event. In fact, in some large and important activities, the timeline is the most standard key performance to measure the success of an activity (Villazón, et al. 2020). The counseling activity was carried out for 90 minutes which in detail can be seen in table 1.

Table 1. Evaluation of Timeliness and Duration

\begin{tabular}{|c|c|c|c|c|}
\hline Indicators & Time & Plot & Evaluation & Likert Scale \\
\hline $\begin{array}{l}\text { Greetings and } \\
\text { Introductions }\end{array}$ & $08.30-08.40$ & $10^{\prime}$ & $\begin{array}{c}0^{\prime} \\
(08.30-08.40)\end{array}$ & 4 \\
\hline $\begin{array}{l}\text { Pre-Implementation } \\
\text { Evaluation }\end{array}$ & $08.40-08.50$ & $10^{\prime}$ & $\begin{array}{c}+2 \\
(08.40-08.52)\end{array}$ & 4 \\
\hline Lecture Main Material & 08.50-09.35 & $45^{\prime}$ & $\begin{array}{c}-3^{\prime} \\
(08.52-09.34)\end{array}$ & 4 \\
\hline Discussion & 09.35- 09.45 & $10^{\prime}$ & $\begin{array}{c}+7 \\
(09.34-09.51)\end{array}$ & 3 \\
\hline $\begin{array}{l}\text { Post-Implementation } \\
\text { Evaluation }\end{array}$ & $09.45-09.55$ & $10^{\prime}$ & $\begin{array}{c}+3 \\
(09.51-10.04)\end{array}$ & 4 \\
\hline Conclusion and Closing & 09.55-10.00 & $5^{\prime}$ & $\begin{array}{c}+1^{\prime} \\
(10.04-10.10)\end{array}$ & 4 \\
\hline & $\begin{array}{c}\text { Total } \\
\text { Duration }\end{array}$ & $90^{\prime}$ & $100^{\prime}$ & 3 \\
\hline & Total Poin & & & 23 \\
\hline
\end{tabular}

Parameters:

1: Not on time $>16^{\prime}$

2: Less on time 11-15'

3: Quite Punctual 6-10'

4: Very Punctual $<5$

Table 1 shows that the total plot of the planned duration for the extension activities is 90 minutes. However, in practice the activity was completed within 100 minutes. So, in general it can be concluded that the extension activities are quite timely with a total of 23 points. Although the extension activities are 10 minutes longer than the predetermined target, the excess duration in each session is still within a reasonable range. The longest excess of duration occurred during the discussion session (+7 minutes) because participants had a high enough curiousity with more detailed knowledge of the subject matter presented.

\section{Participation}

Participation referred to in this activity is the involvement of the target or subject of physical and psychological activities in outreach activities (Haldane et al., 2019). The purpose of participation is the success or achievement of a community target and goal. Physically present in activities, psychologically providing good feedback on the entire series of activities. This shows that individuals understand the benefits that will be obtained from a community service (Sule, 2004). Therefore, the value of participation is measured based on the number and responses of participants during the activity.

The number of participants who were invited to this activity were 75 people with community inclusion criteria in Pamarican Village, married and willing to participate in the activity from beginning to end voluntarily. However, there were eight people who did not attend due to illness and other reasons, bringing a total of 67 participants. Participants who are sick or hyperthermic during temperature checks before entering the room, are not allowed to join the activity and are advised to go home. 
Feedback or participant response is measured by the involvement of participants in the prepost implementation evaluation process and discussion sessions (Tesfaye \& Berhanu, 2015). The participant's response shows that there is motivation to benefit from the information conveyed (Hamidun, Hashim, \& Othman, 2013). In detail, the participation assessment can be seen in Table 2.

Table 2. Participation Evaluation

\begin{tabular}{lcccc}
\hline \multicolumn{1}{c}{ Indicators } & Target & Participants & Poin & $\begin{array}{c}\text { Likert } \\
\text { Scale }\end{array}$ \\
\hline Number of Attendance & 75 & 67 & $89.33 \%$ & 4 \\
Pre-Implementation Evaluation Feedback & 6 & 5 & $83.33 \%$ & 4 \\
Feedback Discussion & 6 & 5 & $83.33 \%$ & 4 \\
Post-Implementation Evaluation Feedback & 6 & 6 & $100.00 \%$ & 4 \\
\hline \multicolumn{1}{r}{ Total } & 93 & 83 & $89.24 \%$ & 4 \\
\hline
\end{tabular}

Parameters:

1 : No Participate $\quad$ with poin of participate $\leq 25 \%$

2 : Less Participate with poin of participate $26 \%-50 \%$

3: Quite Participate with poin of participate $50 \%-75 \%$

4: High Participate with poin of participate $\geq 75 \%$

The indicator on the highest participation dimension gets a score of $100 \%$ in the postimplementation evaluation session. This shows a high motivation to answer all the questions given by the resource person to the participants. This conclusion is reinforced by Kubischta (2014) which states that asking questions and discussing in a lesson is a strategy to increase motivation.

In the discussion session, the two terms that were planned for six people turned out to be only filled by five questioners. This happened not because it did not meet the target, but because it was adjusted to the available time limit. Therefore, it is very important to pay attention to time considerations so that community service activities in the form of counseling or health education are further extended. The time plot and duration of the discussion session can be set at the time of SAP preparation so that the time set is effective and efficient. So that all participants who have the drive to be active in the discussion session can be accommodated (Sudiarti, 2021).

\section{Knowledge}

Knowledge is a series of study activities to find explanation, or a method for obtaining a rationalempirical understanding of the world in various aspects, including health. Health promotion with counseling is one of the activities that can be observed to become new knowledge or strengthen and clarify old knowledge. So, an important indicator that must be included in the evaluation sheet is the knowledge status of the participants (Roring, Posangi, \& Manampiring, 2020).

The results of the observations documented in the evaluation sheet showed an increase in participants' knowledge. Pre-Implementation Evaluation shows that two out of five people who provide feedback on the questions given, can answer the questions correctly. However, after the health education, six participants who gave feedback answered correctly. This shows a change in the status of knowledge, before and after the counseling is carried out.

\section{Job Description}

Job description is an effort to control the role of everyone involved in an activity. The description of each person's duties and functions becomes more organized so that it supports the success of an event. The health promotion carried out involves the professional institution LazisMu, Ciamis Regency, so that all assessments of the Job Description are only measured by the presence or absence of important problems that occur during the activity, who will handle them, and how to overcome them. This point is an indicator of the success of an event. However, 
all activities took place according to the target, so that the job description indicators were considered adequate for the health promotion.

\section{Problem Solving}

In an activity, the potential and risk of problems cannot be avoided. However, careful preparation needs to be done to predict various possibilities that will occur so as to reduce the essence of an event. These predictions relate to the prepared solution. However, this activity can take place without any essential constraints and obstacles.

\section{CONCLUSION}

In accordance with the evaluation results, health promotion activities with counseling to fulfill nutritional needs and balanced nutrition have succeeded with indicators of Timeliness and Duration, Participation, Knowledge, Job Description and Problem Solving. This activity needs to be encouraged and collaborated with all related elements such as the Health Office, Puskesmas and local community leaders, so that public awareness continues to increase along with the increase in the level of knowledge.

\section{ACKNOWLEDGMENT}

The author would like to thank LPPM STIKes Muhammadiyah Ciamis which has funded the activity, and to LazisMu Ciamis Regency who has participated in collaborating.

\section{REFERENCES}

Astika, T., Permatasari, E., \& Turrahmi, H. (2021). Edukasi Gizi Seimbang bagi Kader Posyandu pada Masa Pandemi Covid-19 sebagai Pencegahan Balita Stunting di Kabupaten Bogor. Pengabdian Dan Pemberdayaan Kesehatan Masyarakat, 1(2), 67-77.

Dara Maulidini Akbar dan Zuhrina Aidha. (2020). Perilaku penerapan gizi seimbang masyarakat kota binjai pada masa pandemi covid-19 tahun 2020. Jurnal Menara Medika, 3(1), 15-21.

Debora Tisa Br H, B. Y. S., \& Wahyudi, A. (2020). Pengaruh edukasi gizi menggunakan media audio visual (video) terhadap pengetahuan dan sikap gizi seimbang. Kesehatan, 2(1), 1924.

Firmansyah, A., Setiawan, H., \& Ariyanto, H. (2021). Studi Kasus Implementasi Evidence-Based Nursing: Water Tepid Sponge Bath Untuk Menurunkan Demam Pasien Tifoid. Viva Medika: Jurnal Kesehatan, Kebidanan Dan Keperawatan, 14(02), 174-181.

Fitri, Y., Hendra, A., \& Rahmad, A. (2020). Effect of nutritional counseling about traditional food for children knowledge and attitude. Jurnal AcTion: Aceh Nutrition Journal, 2020(5), 13-18.

Haldane, V., Chuah, F. L. H., Srivastava, A., Singh, S. R., Koh, G. C. H., Seng, C. K., \& LegidoQuigley, H. (2019). Community participation in health services development, implementation, and evaluation: A systematic review of empowerment, health, community, and process outcomes. PloS One, 14(5), e0216112-e0216112. https://doi.org/10.1371/journal.pone.0216112

Hamidun, N., Hashim, S. H. M., \& Othman, N. F. (2013). Enhancing Students' Motivation by Providing Feedback on Writing: The Case of International Students from Thailand. International Journal of Social Science and Humanity, 2(6), 591-594. https://doi.org/10.7763/ijssh.2012.v2.179

Hidayah, S. N., Izah, N., \& Andari, I. D. (2020). Peningkatan Imunitas dengan Konsumsi Vitamin C dan Gizi Seimbang Bagi Ibu Hamil Untuk Cegah Corona Di Kota Tegal. Abdinus, 4(1), 170 174.

Kubischta, F. (2014). Engagement and Motivation: Questioning students on study- motivation, engagement and study strategies. (U. of A. Sciences, Ed.). HAAGA-HELIA. Retrieved from https://www.theseus.fi/bitstream/handle/10024/78341/Kubischta 
Final.pdf?sequence $=1$

Mahmudah, R. L. (2020). Efektivitas promosi peningkatan gizi pada ibu hamil kekurangan energi kronik studi di wilayah kabupaten mojokerto. Medica Majapahit, 12(1), 25-35.

Ronitawati, P., Sitoayu, L., Nuzrina, R., \& Melani, V. (2020). Edukasi bekal sehat berdasarkan prinsip gizi seimbang dengan media " isi bekalku " pada siswa sekolah dasar. JMM (Jurnal Masyarakat Mandiri), 4(3), 407-414.

Roring, N. M., Posangi, J., \& Manampiring, A. E. (2020). Hubungan antara pengetahuan gizi , aktivitas fisik, dan intensitas olahraga dengan status gizi. Biomedik, 12(28), 110-116. https://doi.org/DOI: https://doi.org/10.35790/jbm.12.2.2020.29442

Setiawan, H., Ariyanto, H., Firdaus, F. A., \& Khaerunnisa, R. N. (2021). pendidikan kesehatan pencegahan skabies di pondok pesantren al-arifin. Martabe, 4(1), 110-117.

Setiawan, H., Ariyanto, H., Khaerunnisa, R. N., Firdaus, F. A., \& Fitriani, A. (2021). Yoga Improves Quality of Life among Breast Cancer Patients. Faletehan Health Journal, 8(01), 1-9. https://doi.org/10.33746/fhj.v8i01.159

Setiawan, H., Khairunnisa, R. N., \& Oktavia, W. (2021). Handwashing Health Education to Prevent Covid-19 Transmission in SMP Inspirasi. Abdimas UMTAS, 4(1), 428-432.

Setiawan, H., Sopatilah, E., Rahmat, G., Wijaya, D. D., \& Ariyanto, H. (2018). University Research Colloqium 2018 STIKES PKU Muhammadiyah Surakarta Hubungan Tingkat Pengetahuan dengan Kecemasan Penderita Diabetes Mellitus, 241-248.

Sudiarti, T. (2021). Pengaruh Penyuluhan terhadap Peningkatan Pengetahuan Gizi dan Kesehatan pada Ibu Balita di Mampang, Depok. Jurnal Gizi Kerja Dan Produktivitas, 2(1), 9-14.

Sule, S. S. (2004). Community participation in health and development. Nigerian Journal of Medicine : Journal of the National Association of Resident Doctors of Nigeria, 13(3), 276281.

Tesfaye, S., \& Berhanu, K. (2015). Improving students ' participation in active learning methods: Group discussions, presentations and demonstrations: A case of Madda Walabu University Second Year Tourism Management Students of 2014. Journal of Education and Practice, 6(22), 29-33.

Tuwu, D. (2020). Kebijakan pemerintah dalam penanganan pandemi covid-19. Publicuho, 3(2), 267-278. https://doi.org/10.35817/jpu.v3i2.12535

Villazón, C. C., Pinilla, L. S., Olaso, J. R. O., Gandarias, N. T., \& de Lacalle, N. L. (2020). Identification of key performance indicators in project-based organisations through the lean approach. Sustainability (Switzerland), 12(15). https://doi.org/10.3390/su12155977 


\section{APPENDIX}

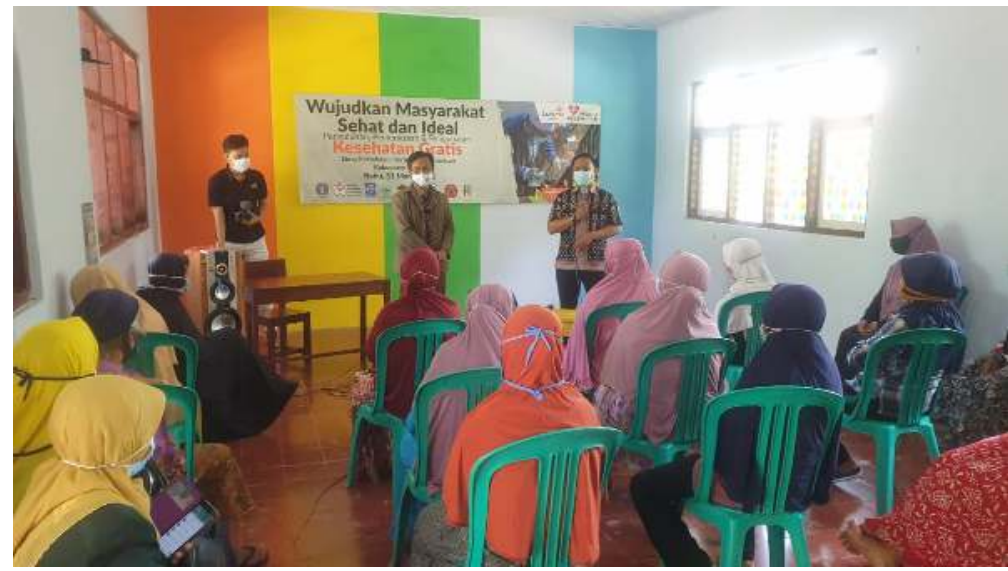

Figure 1. Pre-post Implementation Evaluation

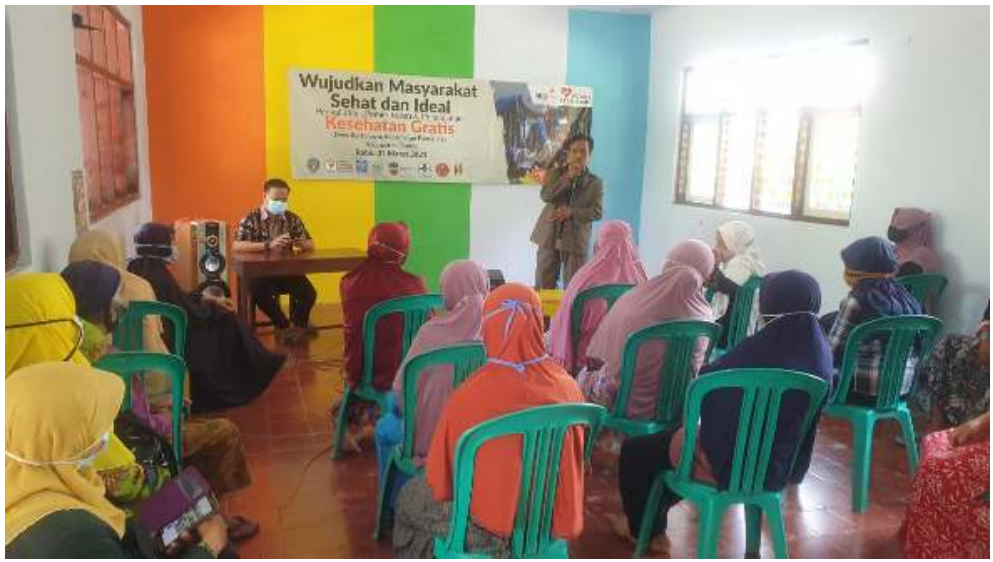

Figure 2. Lecturing of The Main Material and Discussion 